Завершающий этап - подведение итогов предполагает ясность и осознанность со стороны обучающихся, принятие на себя ответственности за достижение цели.

Коучинговое обучение в рамках реализации дополнительной к высшему профессиональной образовательной программы «Преподаватель» строится на таких принципах (по М. Эриксону): 1) у каждого обучающегося есть все необходимые ресурсы для достижения своих целей, поэтому каждый может научиться тому, чему он хочет; 2) у каждого действия есть изначально позитивное намерение; 3) в приоритете настоящее и будущее, важно избегать застревания в прошлом; 4) разделение ответственности; 5) отсутствие советов; 6) безоценочная позиция обучающего; 7) экологичная помощь в развитии потенциала обучающихся.

Достижению профессиональной и личной успешности обучающихся в дополнительном профессиональном образовании способствует создание адекватных организационно-педагогических условий, результатом реализации которых, выступает: развитие их коммуникативных, прогностических и организаторских способностей, владение умениями целеполагания, анализа и структурирования информации, эффективное управление временем, умение работать в команде, быстро принимать решения и преодолевать конфликты, ориентироваться на сильные стороны других людей и собственные достижения.

$$
* * *
$$

1. Гуляев В.Н. Педагогический коучинг в профессиональном образовании студента // Актуальные проблемы и перспективы развития профессионально-педагогического образования студентов: Материалы Международной научно-практической конференции. - 2011. - С. 21-26.

2. Зиневич О.В., Петрова Э.Д. Реализация гуманистической модели образования через развитие коучинга // Философия образования. - 2013. - №4 (49). - С. 144-152.

3. Саволайнен Г.С. Коллаборативный коучинг в дополнительном профессиональном образовании педагогов: идея, технология, практика // Вестник Красноярского государственного педагогического университета им. В.П. Астафьева. - 2014. - № 3 (29). - С.6-11.

4. Серякова С.Б. Компетентностный подход в профессиональной подготовке педагогов дополнительного образования // Глобальный научный потенциал. - 2017. № 10 (79). - С.119-121.

5. Серякова С.Б., Кравченко В.В. Дополнительное профессиональное образование в России и странах Западной Европы. Сопоставительный анализ / Монография. - М.: Прометей. - 2016. - 164 с.

\title{
Панфилова Е.Е. \\ Методические рекомендации по организации профориентационной работы с обучающимися в системе образования «школа-колледж-ВУЗ»
}

Государственный университет управления

(Россия, Москва)

doi 10.18411/spc-04-03-2018-14

idsp 000001:spc-04-03-2018-14

Грамотная организация профориентационной работы в системе образования «школа-колледж-ВУЗ» очень важна в современных условиях развития высокотехнологичных секторов экономики, информационных технологий и новых открывающихся возможностей выстраивания своей профессиональной траектории развития для обучающихся. Приведем ряд методических рекомендаций по организации профориентационной работы с обучающимися, основанных на обобщении практического опыта работы кафедры «Управление организацией в машиностроении» Института отраслевого менеджмента Государственного университета управления (ГУУ):

1. Выделение на кафедре на постоянной основе лица, ответственного за осуществление профориентационной деятельности и набор на образовательные программы бакалавриата и магистратуры. 
2. Включение лица, ответственного на кафедре за профриентационную работу, в состав приемной комиссии ГУУ в качестве секретаря для обеспечения притока студентов на образовательные программы кафедры.

3. Определение перечня (круга) функциональных обязанностей лища, ответственного за профориентационную работу на кафедре:

- характер и периодичность взаимодействия с внутренними структурами ВУЗа (центр довузовской подготовки «АЗ», Центр выпускников, Отдел практики, Отдел по связям с общественностью и т.д.);

- направления взаимодействия с внешними структурами (образовательные организации, Центры дистанционного обучения, технополисы, промышленные предприятия реального сектора экономики, консалтинговые фирмы, тренинговые компании и пр.);

- разработка регламентной отчетности по профориентационной работе (планы, отчеты, информационные справки для размещения на сайте ГУУ);

- участие в проведении «пассивных» мероприятий в рамках профориентационной работы (Дни открытых дверей ВУЗа, института отраслевого менеджмента, кафедры, экскурсии);

- разработка содержательной части активных мероприятий профориентационной деятельности;

- участие в проведении «активных» мероприятий в рамках профориентации (мастер-классы, квесты, деловые игры);

- участие в подготовке и заключении Соглашений о сотрудничестве между кафедрой Университета и образовательными организациями и технополисами, предприятиями;

- расширение числа участников проекта по профориентационной деятельности с использованием ИТ-технологий;

- поддержание и развитие установленных контактов с организациями при осуществлении профориентационной работы (сотрудничество с Национальным центром профессиональной ориентации / ncpo.ru / в рамках сотрудничества с кураторами; реализация образовательных программ с использованием онлайн курсов в рамках Договоров о сетевой форме сотрудничества).

Вариант сетевого взаимодействия в рамках профориентационной работы используется в большей степени для позиционирования бренда ВУЗа посредством подготовки качественных онлайн курсов для освоения бакалаврских программ и их дальнейшего перезачета в ВУЗах-партнерах и привлечения потенциальных абитуриентов на магистерские программы обучения. Таким образом, речь идет о выстраивании траектории профессионального развития уже студента, не абитуриента, в ВУЗовской среде, продвижение не в рамках научной школы кафедры конкретно взятого института, а заимствования опыта межвузовской среды.

4. Формирование ответственным за профориентационную работу окончательного варианта потенциального контингента абитуриентов, претендующих на образовательные программы кафедры, по результатам:

- общения с родителями на родительских собраниях;

- прохождения обучающимися МГОК (школ, колледжей) квестов и деловых игр;

- рекомендаций классного руководителя и наставников (тьюторов).

5. Разработка для обучающегося индивидуальной траектории профессионального развития в рамках системы взаимодействия «школа-колледж- 
ВУЗ», т.е. определение рекомендуемых образовательных программ для поступления, форм и сроков обучения в ВУЗе и колледжах-партнерах с учетом предоставляемых возможностей со стороны технополиса «Москва».

6. Составление ответственным за профориентационную работу индивидуального годового плана мероприятий для обучающегося, включающего посещение квестов, мастер-классов в колледжах-партнерах и ВУЗе, экскурсий в компании-резиденты технополиса, конференциях, конкурсах проектов и иных научноисследовательских мероприятия. Форма индивидуального плана профориентационных мероприятий для обучающегося представлен в см. табл. 1.

7. Закрепление каждого обучающегося из сформированного контингента потенцииальных абитуриентов за определенным преподавателем кафедры в целях научного консультирования.

8. Контроль лицом, ответственным за профориентационную деятельность, результатов прохождения обучающимся каждого из этапов сформированного персонального плана.

9. Анализ причин отклонения от сформированной траектории профессионального развития у обучающегося (отсутствие на мастер-классах, несвоевременная сдача отчета по совместно реализуемой проектной деятельности и т.д.).

Таблийа 1

Индивидуальный план профориентацчионных мероприятий

\begin{tabular}{|c|c|c|c|c|c|}
\hline $\begin{array}{c}\text { Вид } \\
\text { профориентационного мероприятия }\end{array}$ & сентябрь & октябрь & .. & май & $\begin{array}{c}\text { Летние } \\
\text { месяцы, } \\
\text { иное } \\
\text { каникулярн } \\
\text { ое время } \\
\text { (смены) }\end{array}$ \\
\hline \multicolumn{6}{|l|}{$\begin{array}{c}\text { 1.Квест по поступлению в ВУЗ «Я - } \\
\text { абитуриент» }\end{array}$} \\
\hline \multicolumn{6}{|l|}{$\begin{array}{c}\text { 2.Игра по самоопределению «Моя профессия } \\
\text { в будущем» }\end{array}$} \\
\hline \multicolumn{6}{|l|}{ 3.Деловая игра «Работаю в технополисе» } \\
\hline \multicolumn{6}{|l|}{ 4.Тренинг «Менеджер-аналитик» } \\
\hline \multicolumn{6}{|l|}{$\begin{array}{c}\text { 5.Игра на знакомство с образовательными } \\
\text { программами кафедры }\end{array}$} \\
\hline \multicolumn{6}{|l|}{ 6.Смены в лагерях (каникулы) } \\
\hline \multicolumn{6}{|l|}{$\begin{array}{c}\text { 7.Совместная проектная деятельность по } \\
\text { тематике технополиса «Москва» }\end{array}$} \\
\hline \multicolumn{6}{|l|}{$\begin{array}{l}\text { 8.Кейсы от компаний-работодателей (ОАО } \\
\text { «Вертолетный завод им. М.Л.Миля») }\end{array}$} \\
\hline \multicolumn{6}{|l|}{$\begin{array}{c}\text { 9.Мастер-класс «Я - индивидуальный } \\
\text { предприниматель» }\end{array}$} \\
\hline \multicolumn{6}{|l|}{$\begin{array}{c}\text { 10. Всероссийская научно-практическая } \\
\text { конференция «Проблемы управления: } \\
\text { методы, поиск, решения» }\end{array}$} \\
\hline $\begin{array}{l}\text { 11. Онлайн курсы по выбранному } \\
\text { профилю (менеджмент, бережливое } \\
\text { производство, экономика, интернет- } \\
\text { маркетинг и пр.) }\end{array}$ & & & & & \\
\hline
\end{tabular}

10. Проведение корректировок сформированной профессиональной траектории обучающегося с учетом результатов участия в различных мероприятиях, мнения родителей, изменения приоритетов школьника, (поступление на внебюджетную основу) и т.д. финансовых возможностей 
11. Оценка лицом, ответственным за профориентационную работу, планируемых результатов продвижения обучающихся по выбранной траектории профессионального развития.

12. Мониторинг внешних проектов и платформ, связанных с активнымм формированием траекторий профессионального развития и рекомендация их обучающимся. К числу рекомендованных для школьников проектов, на которые имеет смысл обратить внимание, можно отнести следующие:

- участие в образовательной профильной смене «Движение техномира» (https://www.mgpu.ru/centers/startpro/nashi-zanyatiya/obrazovatelnayaprofilnaya-smena-dvizhenie-tehnomira/);

- посещение занятий, предлагаемых Лабораторией профориентации и технологий развития успешности, а также в Лаборатории прикладных и инженерных компетенций (https://www.mgpu.ru/centers/startpro/labs/laboratoriej-proforientatsii-itehnologij-razvitiya-uspeshnosti/);

- прохождение в рамках проекта «Профсреда» тестирования и пробы профессии в реальных компаниях (http://www.profsreda.com/internship);

- выбор смены в профориентационном лагере «Профессионалы будущего» (https://www.proffuture.ru/);

- погружение в гуманитарную или техническую смену в рамках межвузовского профориентационного лагеря «Университет мечты», приобретая за одну неделю каникул знания о деятельности 6 ВУЗов и специфике 12 профессий (http://uniofdreams.ru/).

13. Контроль результатов поступления обучающихся в образовательные организации в системе «колледж-ВУЗ». Для обучающихся, отдавших предпочтение поступлению в колледж-партнер ГУУ, упор делается на поддержание постоянных контактов, приглашение на Дни открытых дверей и мастер-классы с целью будущего обучения на сокращенных программах ВУЗа. Для школьников, поступающих сразу в ВУЗ, ответственный за профориентационную работу передает сформированное портфолио обучающегося куратору группы.

14. Мониторинг ответственным за профориентационную работу продвижения обучающихся по сформированной индивидуальной траектории профессионального развития.

15. Формирование и актуализация базы данных с информацией о местах трудоустройства выпускников образовательной программы кафедры. Вариант структуры одной из таблиц баз данных представлен в табл. 2.

Таблица 2

База данных по выпускникам кафедры «Управление организацией в машиностроении» ГУУ

\begin{tabular}{|c|c|c|c|c|}
\hline $\begin{array}{c}\text { № } \\
\text { пп }\end{array}$ & $\begin{array}{c}\text { Фамилия, имя, отчество } \\
\text { выпускника }\end{array}$ & $\begin{array}{c}\text { Место } \\
\text { работы }\end{array}$ & $\begin{array}{c}\text { Занимаемая } \\
\text { должность }\end{array}$ & $\begin{array}{c}\text { Год } \\
\text { выпуска }\end{array}$ \\
\hline 1 & & & & \\
\hline
\end{tabular}

Другие же таблицы базы данных по выпускникам могут содержать справочную информацию (контактные данные, номера СНИЛСов, паспортные данные, ИНН и т.д.).

16. Поддержание и развитие деловых связей с компаниями-работодателями, технополисом «Москва» в целях дальнейшего трудоустройства выпускников колледжей-партнеров и ВУЗа.

17. Воспитательный момент профориентационной работы - приглашение выпускников образовательных программ кафедры (состоявшихся в профессии) для проведения мастер-классов студентам и школьникам, участия в экспертизе 
образовательных программ кафедры, работе в составе Государственных аттестационных комиссий в качестве председателей и членов, рецензентов учебников, источников для предоставления баз практики студентам и т.д.

Организация профориентационной работы, в соответсвии с вышеприведенными методическими указаниями в системе образования «школа-колледж-ВУЗ» позволит осуществлять подготовку квалифицированных кадров для высокотехнологичных секторов экономики, помогать обучающимся с формированием собственной траектории профессионального развития и получением профессии мечты, востребованной на рынке труда.

Примером апробации разработанных методических рекомендаций по организации профориентационной работы с обучающимися замыкающего звена в цепочке «школа-колледж-ВУЗ» может являться нижеприведенное образовательное мероприятие, схема которого приведена ниже.

Образовательное мероприятие - выездная экскурсия в технополис «Москва» (Волгоградский проспект, 42/13) для студентов 1 курса образовательной программы бакалавриата «Менеджмент промышленных организаций» Института отраслевого менеджмента Государственного университета управления в рамках изучения дисциплины «Основы профессиональной деятельности» (ноябрь 2017 года).

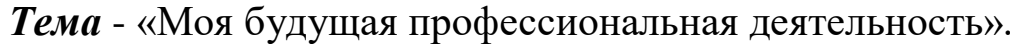

Цель (в соответствии с ценностным подходом) - формирование у студентов представления о возможных сферах своей профессиональной деятельности при знакомстве с опытом работы инновационных высокотехнологичных производств различных кластеров технополиса («Промышленная автоматизация», «Новые материалы», «Энергоэффективность», «Фармацевтика», «Робототехника»).

Задачи образовательного мероприятия:

1. Объяснить особенности организации и управления производственнохозяйственной деятельностью компаний-резидентов высокотехнологичных секторов экономики, располагающихся в технополисе «Москва»; а также обсудить квалификационные требования, выдвигаемые к управленческому составу среднего и высшего звена промышленных организаций (для преподавателя).

2. Понимать преимущества локализации промышленного производства в технополисе для якорных резидентов (для студентов);

3. Проанализировать стратегию развития инновационных производств на территории технополиса (для студентов).

\section{Планируемые результаты:}

1. По итогам проведения экскурсии студенты смогут сформулировать не менее 3-х причин, побуждающих руководство высокотехнологичных организаций размещать свои производственные мощности в особых экономических зонах развития, в т.ч. технополисах.

2. Привести не менее 3-х причин, обуславливающих конкурентоспособность компаний-резидентов технополиса (в долгосрочной перспективе) при выходе на внешний рынок сбыта продукции.

3. Определиться с собственной траекторией будущего профессионального роста посредством выбора специальных дисциплин, формирующих профессиональные компетенции, необходимые при выстраивании управленческих взаимоотношений в плоскости управляющая компания - компания-резидент.

\section{Мотивация: способ вовлечения}

1. Интерес. «Подкидная доска» - в настоящее время технополисы, индустриальные, технологические парки являются своего рода «точками роста» для организаций реального сектора экономики, поскольку концентрируют на своих территориях инновационные/наукоемкие производства, высококвалифицированные управленческие кадры, создают большое число рабочих мест в перспективных отраслях экономики. 
Понять, как функционируют такие инновационные территориальные кластеры (технополис «Москва», «Мосгормаш», «Руднево», «Физтехпарк» и др.) очень важно, поскольку они являются перспективными работодателями и будущая работа может быть связана именно с их развитием и становлением.

2. Проблема. Как выстроить свою индивидуальную образовательную траекторию в Университете, чтобы обладать необходимыми знаниями, навыками, умениями и компетенциями, которые будут цениться у таких работодателей, как технополисы ?

Акцентируем внимание студентов на возможных вариантах получения работы в технополисе посредством активной жизненной позиции через:

- прохождение студентами учебных, производственных, преддипломных практик, стажировок в компаниях-резидентах технополиса с возможностью участия в решении конкретных производственных задач;

- участие в реализации совместных научных мероприятий между технополисом «Москва» и Государственным университетом управления. Например, выступление с докладом на круглом столе, посвященном вопросам конкурентоспособности отечественных промышленных товаров, или выполнение определенного объема работ в рамках хоздоговорной научно-исследовательской работы.

Информируем студентов о том факте, что с креативными и целеустремленными студентами заключаются отсроченные трудовые договора, гарантирующие дальнейшее трудоустройство после окончания ВУЗа.

\section{План мероприятия:}

1. Экскурсия по «Т8-Издательские технологии», издательскому бизнесу с облачной технологией хранения данных и цифровым производством (кластер в технополисе - «Информационно-коммуникационные технологии»).

2. Знакомство с деятельностью «Коптер Экспресс», разработчика и производителя беспилотных летательных аппаратов для образования, автоматической доставки грузов и мониторинга территорий (кластер в технополисе - «Робототехника, промышленная автоматизация»).

3. Посещение Центра проектирования обуви специального назначения «ОРТОМОДА», ориентированного на производство ортопедической обуви по индивидуальному заказу (кластер в технополисе - «Медицинские технологии, оборудование»).

4. Совместное обсуждение (студентами, преподавателем, советником генерального директора технополиса «Москва», Бернером М.С.) специфики функционирования и управления компаниями-резидентами в технополисе в ходе выездной экскурсии и определение путей дальнейшего сотрудничества со студентами.

\section{Рефлексия}

1. По итогам проведения экскурсии студентам на следующее занятие по дисциплине «Основы профессиональной деятельности» принести резюме (объемом 1 стр.) по тематике «Я - управленец в технополисе».

2. Обсудить со студентами следующие вопросы на занятии:

- Организация деятельности какой производственной компании-резидента технополиса показалась нетипичной для своего сектора экономики и почему ?

- По Вашему мнению, знаний в каких профессиональных областях Вам явно не хватает, чтобы найти перспективную работу после окончания ВУЗа в сфере деятельности инновационных технополисов и технопарков ?

- Какой момент в экскурсии по технополису показался скучным и неинтересным ? Аргументируйте.

Аналогичная экскурсия в технополис может быть проведена для школьников Московских государственных образовательных комплексов (МГОК). В этом случае в 
рамках профориентационного мероприятия указываются приобретаемые универсальные учебные действия (УУД), т.е. умение учиться или способность обучающегося к совершенствованию при выстраивании траектории профессионального развития. Фактически УУД по сути своей являются умениями, связанными с осуществлением учебной деятельности во все ее полноте. При организации экскурсии у обучающихся формируются УУД в рамках следующих блоков:

1. Личностные - действия, связанные прежде всего с профессиональным самоопределением.

2. Регулятивные - действия, ориентированные на планирование конечного результата (как вариант заключение отложенного трудового договора, совместное участие в исследованиях, приобретение профессии, востребованной в компанияхрезидентах технополиса).

3. Познавательные

3.1. общеучебные:

- исследовательские, связанные с формулированием гипотезы и еe проверкой;

- умение структурировать знания при решении конкретных кейсов;

- выбор наиболее эффективных способов решения задач в зависимости от конкретных условий;

- оценка полученных результатов по замечаниям представителей компаний-резидентов и рекомендациям преподавателей кафедры;

- умение составлять отчет по результатам выполненного исследования.

3.2. универсальные логические:

- анализ компаний-резидентов с целью выявления общих признаков, обусловивших включение в один из кластеров технополиса;

- выбор критериев для сравнения кластеров между собой внутри технополиса;

- установление причинно-следственных связей, определяющих, например, конкурентоспособность продукции, выпускаемой резидентами, на внешнем рынке.

3.3. постановка и решение проблемы (самостоятельное формулирование обучающимся проблемы и способов ее решения с оценкой возможных рисков предлагаемых решений).

4. Коммуникативные - планирование способов взаимодействия с лицом, ответственным за профориентационную деятельность, преподавателями кафедры, представителями управляющей компании технополиса; разрешение конфликтов в рамках учебной группы, работающей над кейсом; умение выражать свои мысли при публичной защите предлагаемых вариантов решения проблемой ситуации).

Основным приемом, направленным на поддержку универсальных учебных действий и практическую организацию учебно-воспитательного процесса является решение кейсов из практики деятельности компаний-резидентов различных кластеров технополиса «Москва».

Выше приведено стандартное описание образовательного мероприятия, проводимого в рамках профориентационной работы. Учитывая требования ФГОС, а также степень внедрения информационных технологий в образовательный процесс, представляется целесообразным описать данное мероприятие профориентационной работы в рамках Московской электронной школы (МЭШ). Поскольку в рамках МЭШ находится в разработке вкладка для высшей школы, то представляется логичным, что любое образовательное мероприятие (учебное и воспитательное) потребуется описать, опираясь на логику и инструменты данного электронного ресурса.

В рамках профориентационной работы кафедры ВУЗа должна присутствовать взаимозаменяемость, чтобы в случае отсутствия работника (по болезни, командировки, обучения и т.д.) другой сотрудник мог также квалифицированно провести мероприятие, «стиражировать» его на другие колледжи и школы-партнеры ВУЗа. Для 
школьников или обучающихся колледжей, по уважительным причинам отсутствовавшим на профориентационном мероприятии, будет полезным просмотреть материалы из своего личного кабинета и, соответственно записаться на то мероприятие, которое соответствует его интересам и будущей профессии. Сам факт возможности предварительного изучения школьниками и обучающимися колледжей программ профнавигации посредством прохождения в электронном дневнике по вкладкам «Дополнительно» $\rightarrow$ ”Внешние ссылки» $\rightarrow$ «Библиотека МЭШ» представляет колоссальные возможности для выстраивания альтернативных траекторий профессионального развития и продвижения программ ВУЗов.

Разработка сценария урока в МЭШ в форме «Экскурсия в технополис «Москва» в рамках профориентационной работы ВУЗ - школам и колледжам» представлена по адресу: https://uchebnik.mos.ru/composer2/lesson/195429, пароль ученика login04-962, пароль 12345678.

1. Область знаний - экономика, менеджмент, профориентационная работа с различными группами обучающихся.

2. Возрастная группа - школьники 8-9, 10-11 классы, а также студенты 1 курса ГУУ в рамках дисциплины «Основы профессиональной деятельности»; 3,4 курса в рамках учебной и преддипломной практик; магистранты 1,2 курса образовательной программы «Управление промышленным бизнесом» при прохождении учебных, производственных и преддипломных практик. этапов:

Образовательное мероприятие в рамках МЭШ предлагается разбить на ряд

1. Введение в специфику деятельности управляющих компаний и фирмрезидентов в технополисе (рис.1).На диалоговой доске помещен видеоролик, знакомящий обучающихся с инфраструктурой технополиса, его резидентами и особенностями размещения в особой экономической зоне. На планшете лица, ответственного за профориентационную работу, высвечивается своеобразная подсказка о поставленных целях и задачах мероприятия. На планшете учеников отражается активная ссылка на сайт технополиса «Москва» с указанием конкретной презентации, с которой целесообразно ознакомиться в рамках виртуальной экскурсии. Материал представлен в интерактивной форме, предполагает, что школьники совершенствуют навыки работы с информацией и ее поиском. В качестве задания предлагается разнести ряд компаний-резидентов под соответствующие кластеры технополиса.

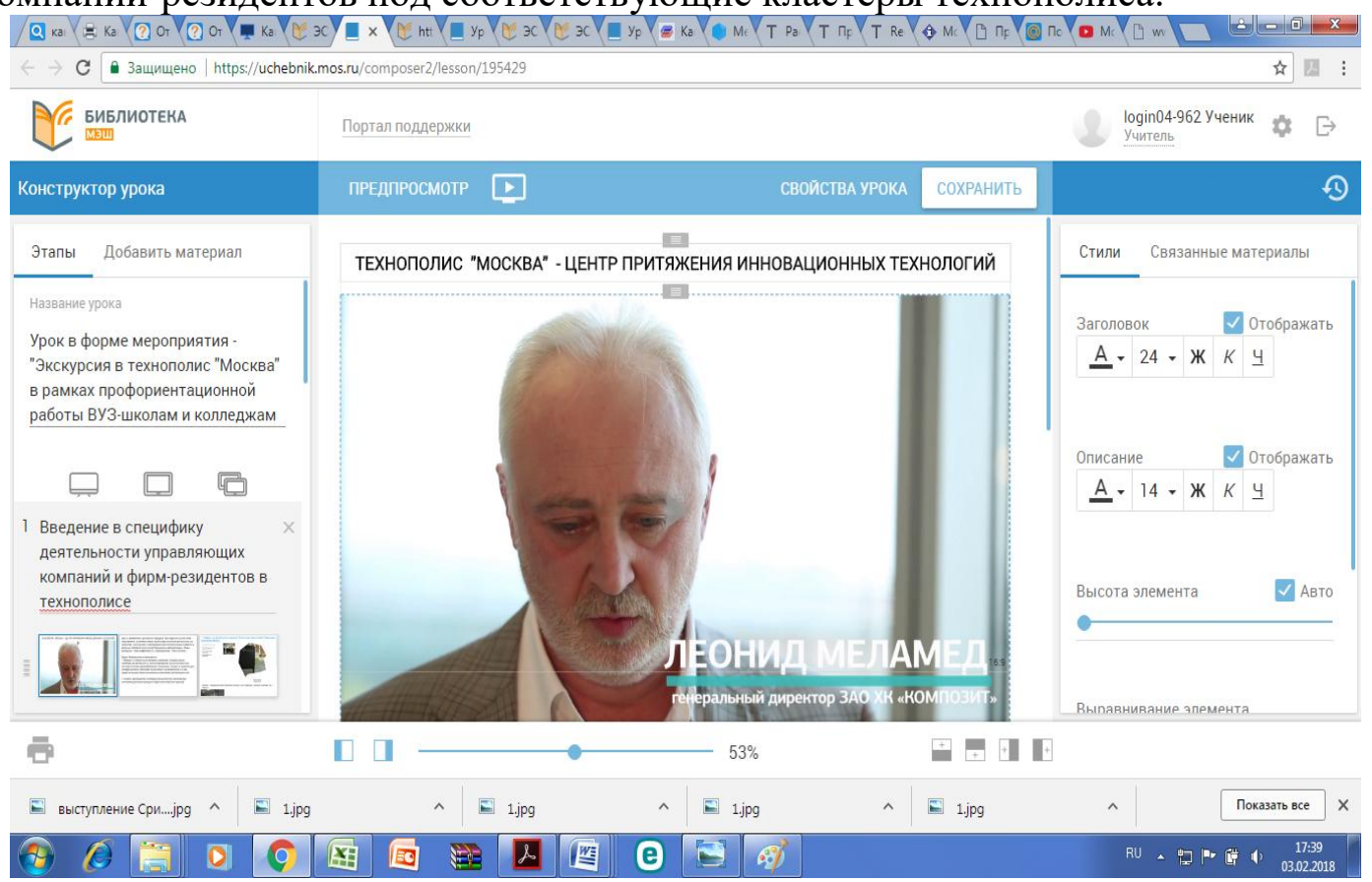

Рис.1 - Этап 1. Введение в специфику деятельности технополиса 
2. Экономические условия функционирования компаний-резидентов в технополисе (рис.2).

На диалоговой доске помещен видеоролик, позволяющий подойти к рассмотрению технополиса и потенциальной возможности найти свое место в нем в будущем, с позиции стратегического инвестора в высокотехнологичное производство, разработчика ИТ-технологий и рядового работника. На планшете лица, ответственного за профориентацию, выдается информация о планируемых результатах по итогам проведения данного образовательного мероприятия. На планшете обучающихся представлена таблица с технико-экономическими параметрами для технополисов и индустриальных парков с тем, чтобы закрепить принципиальное отличие в управлении и функционировании данных объектов инновационной инфраструктуры.

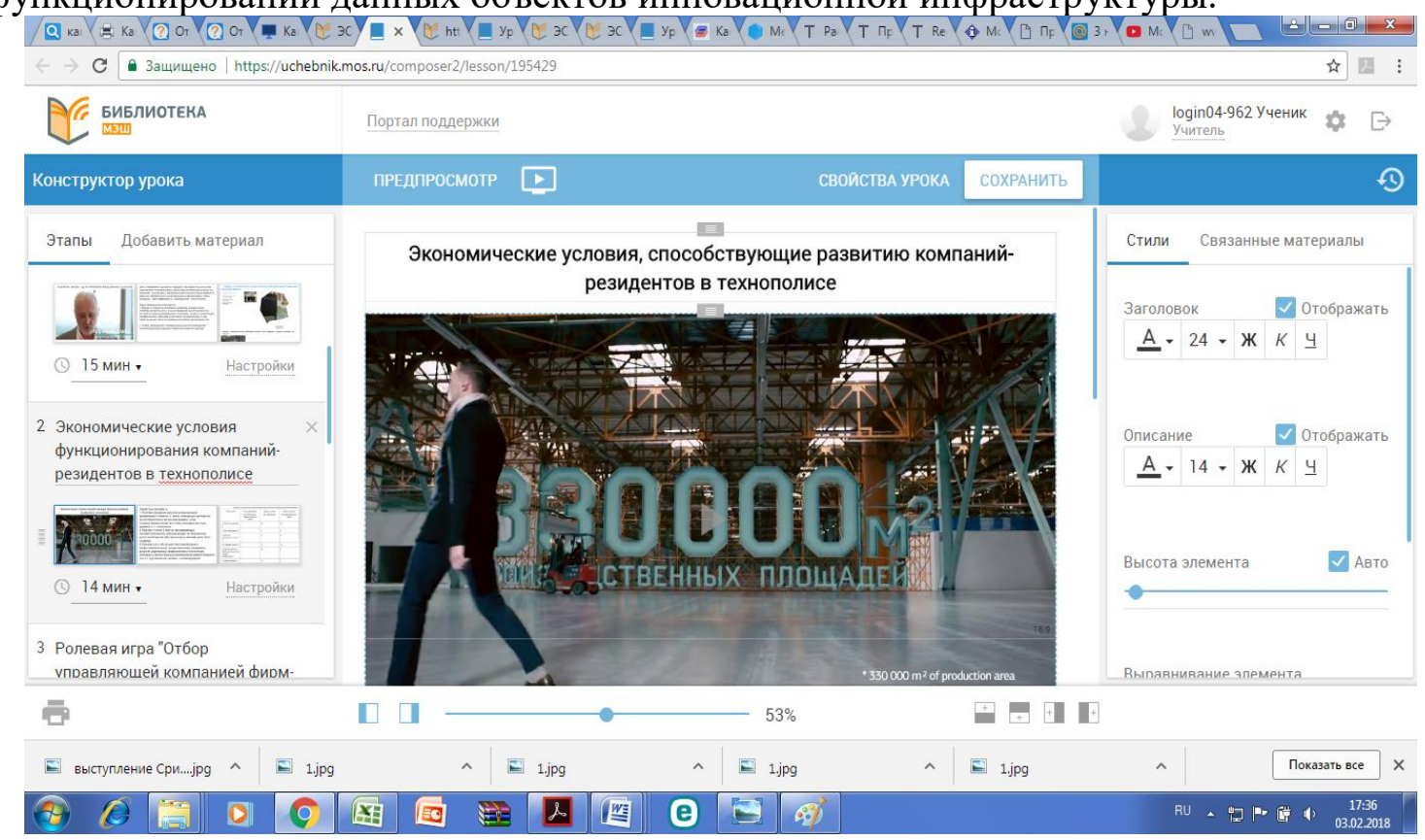

Рис.2- Этап 2.Экономические условия функционирования компаний-резидентов

3. Ролевая игра "Отбор управляющей компанией фирм-резидентов для включения в состав технополиса "Москва" (рис.3).

На интерактивной доске дана схема 15 компонентов современного производства, которая позволяет судить о технологиях управления, проектирования и производства, используемых на конкурентоспособных

предприятиях и требованиях, которые предъявляются к работникам. Дополнительно для изучения материала даются ссылки по раскрытию экономической информации о деятельности технополиса и атласа профессий, которые появятся после 2020 года. На планшете ответственного за профориентацию выдается подсказка о развитии у обучающихся навыков проектной деятельности при осуществлении техникоэкономического обоснования проектов для промышленных организаций, размещаемых на территории технополиса. На планшетах школьников / студентов высвечиваются интерактивные задания, связанные с проработкой условий и требований, предъявляемых к субъекту малого инновационного предпринимательства для включения в число резидентов. Например, обоснованием величины запрашиваемой компанией производственной площади, исходя из арендной ставки, или соблюдением требований на технологическую новизну изделия. Таким образом, при выполнении кейсов, реальных заданий из практики деятельности компаний обучающиеся смогут сориентироваться в какой плоскости находится их профессиональный интерес производство, управление, информационная поддержка и сопровождение процессов и т.д. 


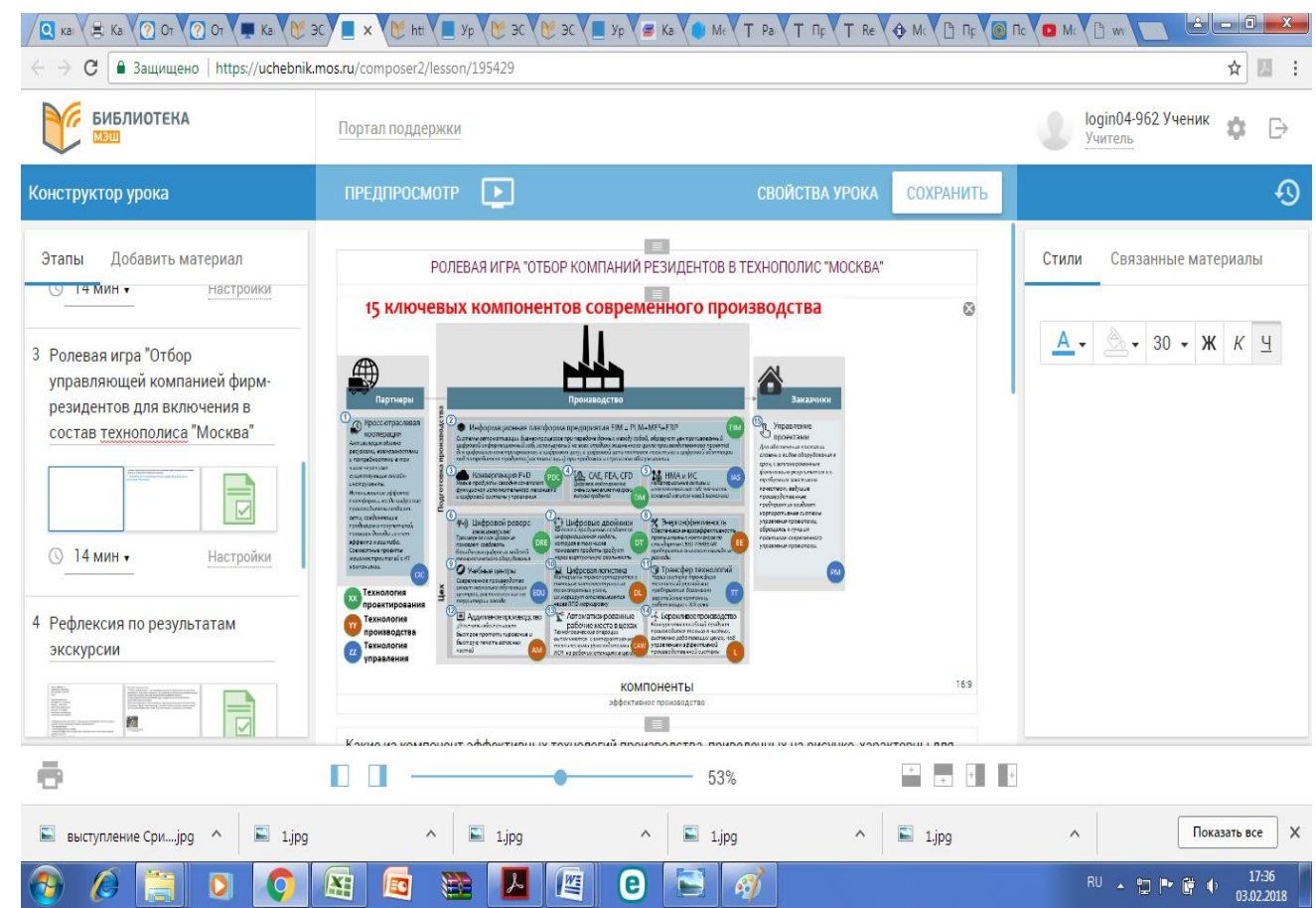

Рис.3 - Этап 3. Ролевая игра «Отбор УК резидентов»

4. Рефлексия по результатам экскурсии (рис.4).

На интерактивной доске высвечивается тематика проектных работ, выполнение которых возможно при поддержке компаний-резидентов (исходя из предварительно выбранных обучающимися кластеров технополиса), а также предложено написать в свободной форме эссе, отразив приоритеты при выборе образовательных программ ВУЗа. На планшете ответственного за профориентационную работу представлена в качестве мини-подказки информация о способах мотивации обучающихся для участия в мероприятиях, направленных на выявление и выстраивание тренда своей будущей профессиональной траектории.

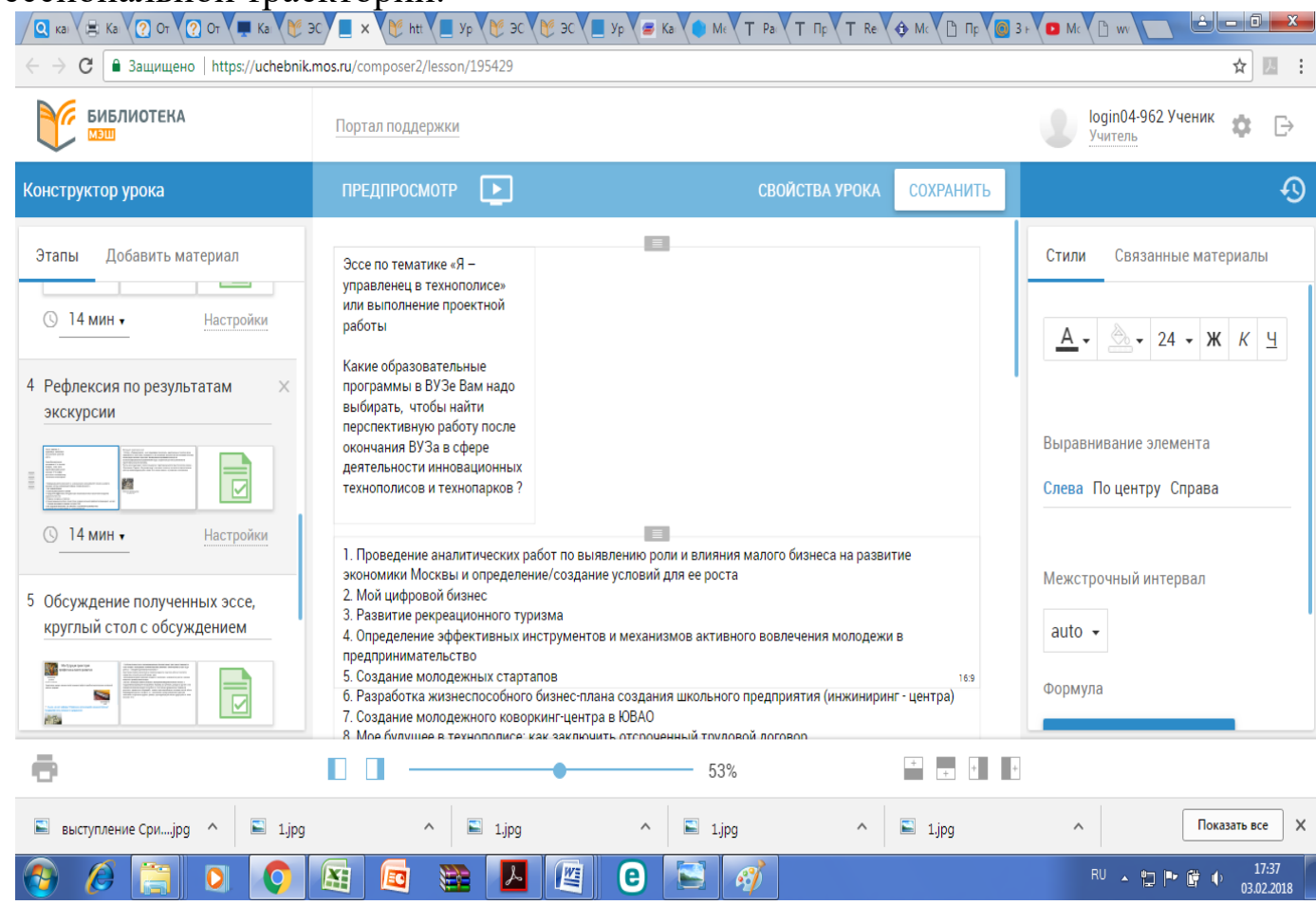

Рис. 4 -Этап 4. Рефлексия по результатам экскурсии 
На планшетах обучающихся представлен интерактивный объект в виде фрагмента теста, направленного на закрепление изученного материала по организации и управлению компаний-резидентов, особенностям функционирования управляющей компании. Фактически технопарк, насчитывая около 92 резидентов в своем составе, одновременно относящихся к различным секторам экономики, позволяет школьникам и студентам оценить различие в управлении производством для фирм различного масштаба и сферы деятельности. Это учитывается при формировании дисциплин по выбору в рамках учебного плана для студентов и магистрантов.

5. Обсуждение полученных эссе, круглый стол с обсуждением (рис.5).

На интерактивной доске высвечивается вопрос для обсуждения «Какие именно знания, умения, навыки и компетенции необходимы выпускнику школы, колледжа или ВУЗа для того, чтобы найти достойную и интересную работу в будущем?», а также ссылка на сайт кафедры «Управление организацией в машиностроении» ГУУ и координаты лица, ответственного за профориентационную работу.

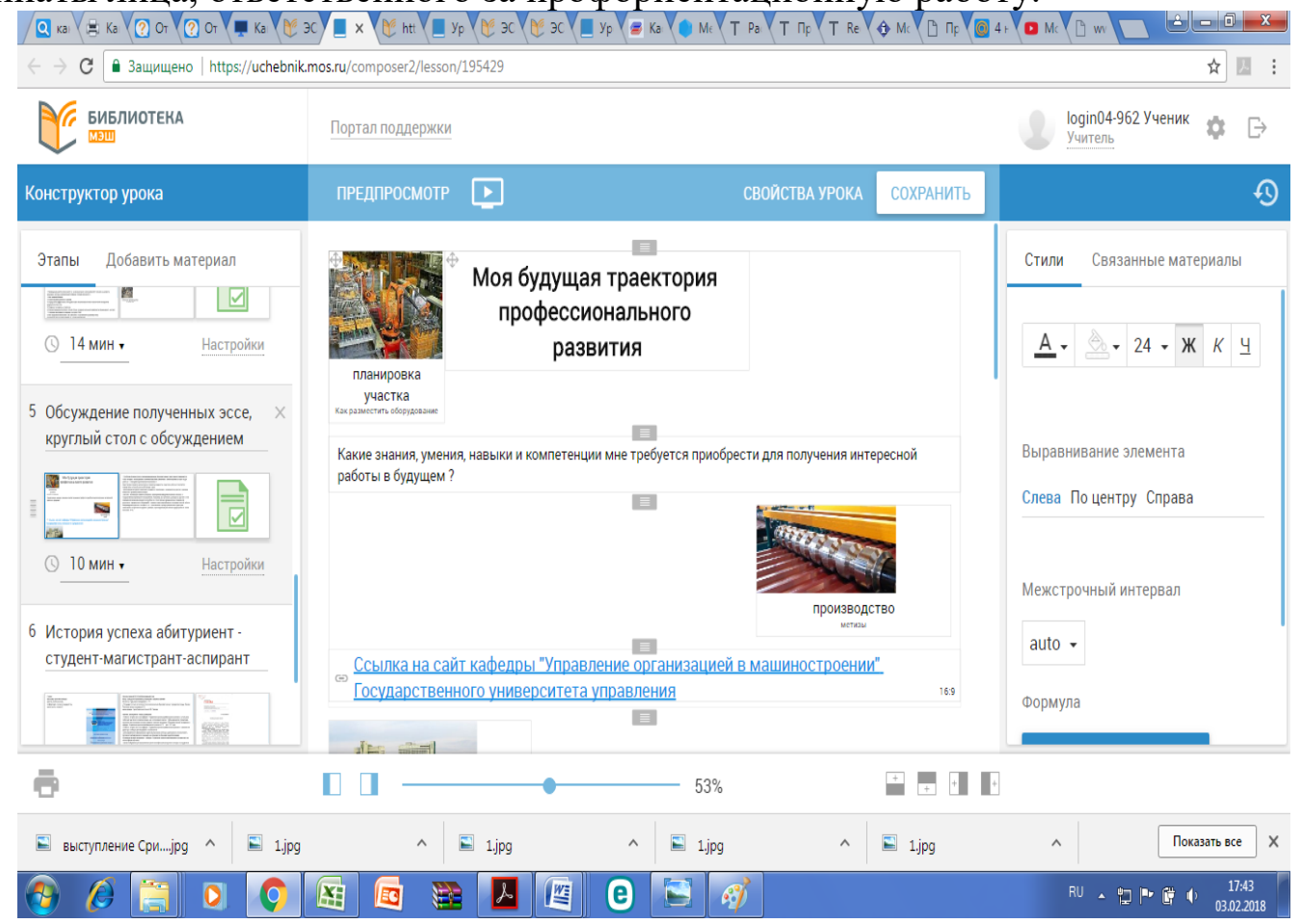

Рис. 5 - Этап 5. Обсуждение полученных эссе, кругльй стол

На планшете лица, ответственного за профориентационную работу, выдается текст-напоминание о потенциальных возможностях для обучающихся с точки зрения заключения отложенного трудового договора с технополисом, участия в научнотехнических мероприятиях $\mathrm{c}$ ориентацией на возможность выстраивания индивидуальной профессиональной траектории, совмещения работы с обучением в бакалавриате, магистратуре, аспирантуре. На планшетах обучающихся «всплывает» интерактивный объект, позволяющий заполнить форму эссе «Я - управленец в технополисе».

6. История успеха абитуриент - студент-магистрант-аспирант (рис.6).

На интерактивной доске в качестве наглядного примера приведена траектория движения обучающегося по цепочке абитуриент - потенциальный магистр с иллюстрацией сертификатов, полученных в ходе выполнения грантов, участия в конференциях и пр. 


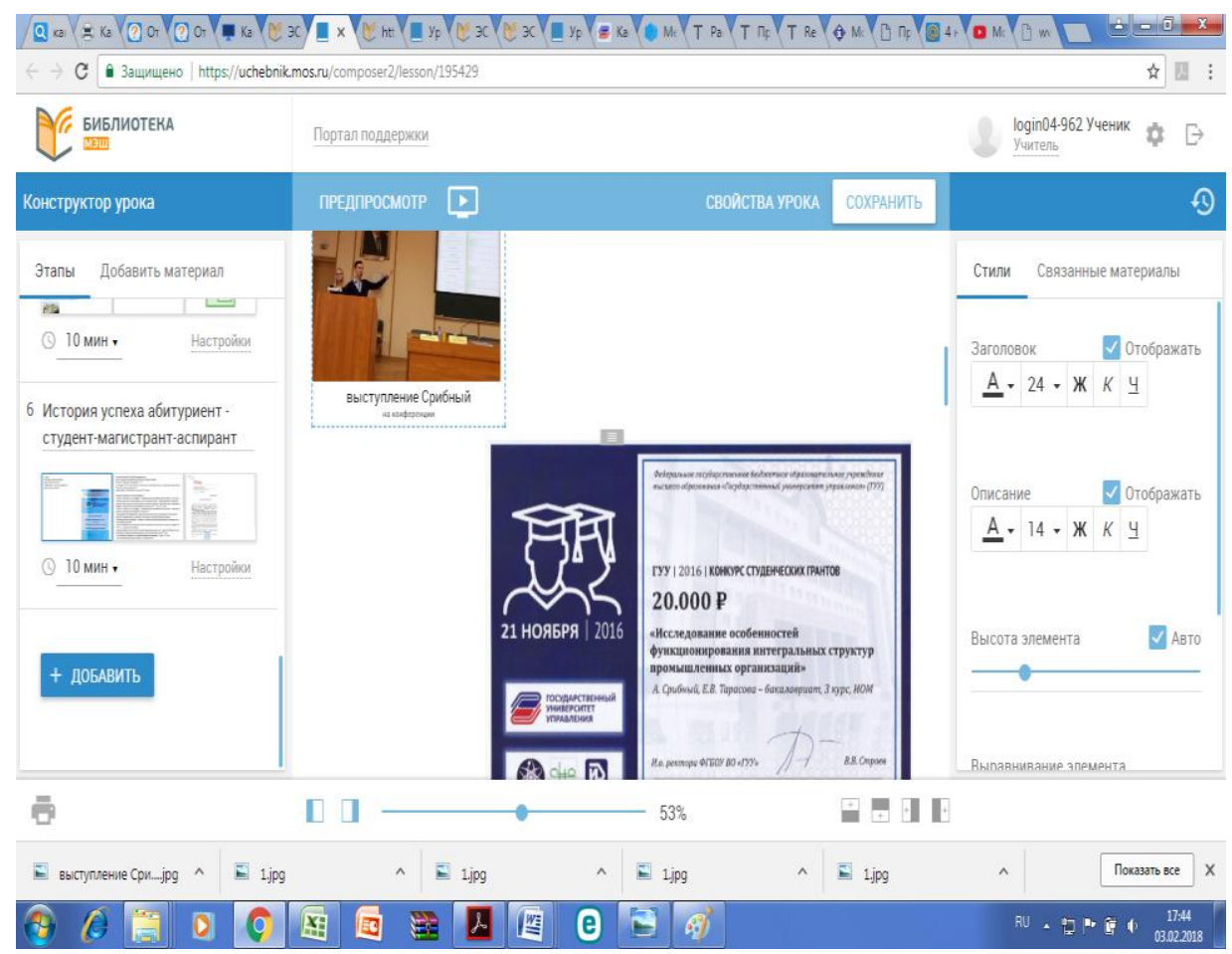

Этап 6. История успеха абитуриент-бакалавр-магистрант

На планшете лица, ответственного за профориентацию, представлен типовой образец программы взаимодействия кафедры ВУЗа и МГОКов, колледжей при обсуждении возможностей выстраивания индивидуальных траекторий обучения в рамках учебных планов, перехода на сокращенные формы обучения путем взаимозачета пройденных дисциплин, читаемых совместно. На планшете обучающегося приведен пример рекомендательного письма, выданного студенту, по результатам прохождения практик и стажировок в технополисе «Москва» для предоставления возмоности бесплатного обучения по образовательной программы магистратуры.

Таким образом, возможность прохождения виртуальной экскурсии в технополис «Москва» позволяет ответственному за профориентационную деятельность в дальнейшем правильно группы обучающихся для реального посещения компанийрезидентов, сообразовываясь с интересами школьников / студентов.

В рамках системы образования «школа-колледж-ВУЗ» индивидуальная траектория обучения принципиально может быть выстроена в следующем ключе:

- школа-колледж, школа-колледж-ВУз;

- школа-колледж-технополис;

- школа-колледж-технополис (ВУЗ, программа бакалавриата/магистратуры с обучением на очно-заочной или заочной формах обучения);

- МГОК-ВУЗ, МГОК-технополис-ВУЗ.

Принципиальные точки взаимодействия кафедры ВУЗа, МГОКов и колледжей с предприятиями реального сектора экономики представлены на рисунке 7.

Фактически возникает синергетический эффект сетевого взаимодействия между всеми участниками профориентационной деятельности. Следует учитывать немаловажный факт, что в настоящее время реализована современная образовательная платформа «Открытое образование» (https://openedu.ru/), позволяющая обучающимся получить бесплатно доступ к онлайн курсам в рамках освоения базовой части дисциплин учебного плана с возможностью получения сертификатов и зачетом определенного количества часов. Это представляет определенного рода конкуренцию и 
возникает потребность в разработке узкоспециализированных, профильных курсов, исходя из потребностей компаний-резидентов технополиса.

Для классов с предпрофильной профилизацией (7-8 классы) при проведении профориентационных мероприятий имеет смысл использовать флипчарт программу «ActivInspire», поскольку она позволяет отработать навыки работы с бухгалтерской отчетностью, заполнения деклараций и составления отдельных разделов бизнес-плана. Такой подход сразу выделит школьников, имеющих склонность к аналитической работе с цифрами, отчетами и документацией.

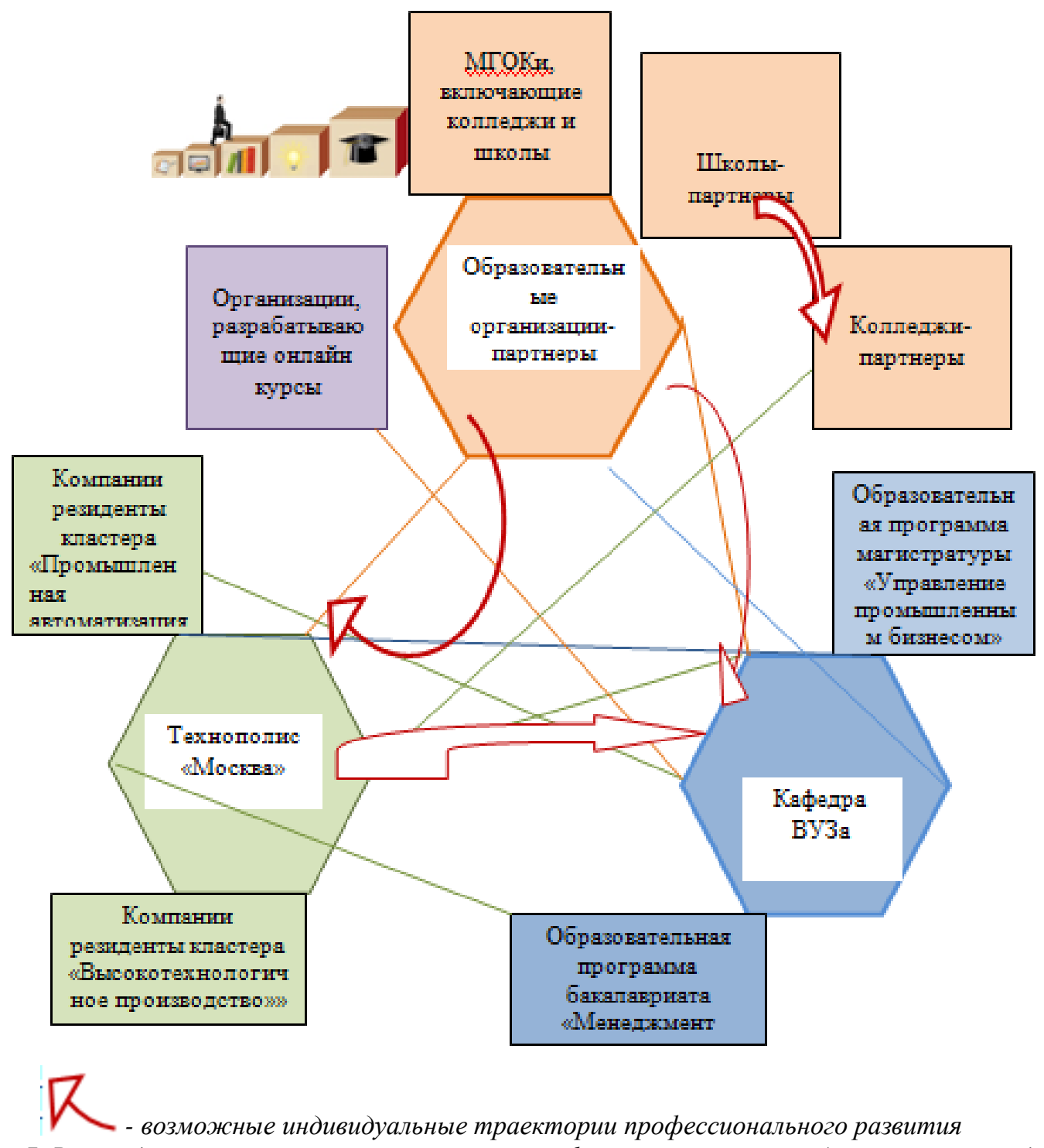

Рисунок 7. Взаимодействие лиц, ответственных за профориентационную работу, в рамках модели школа-колледж-Вуз и предприятия реального сектора экономики.

Под педагогической технологией, используемой в рамках профориентационной paботы, будем понимать совокупность форм, методов, способов, приемов обучения и воспитательных средств, комплексно используемых в системе образования «школаколледж-ВУЗ» при выстраивании индивидуальной образовательной траектории обучающегося, приводящая к достижению прогнозируемого образовательного результата - поступление на приоритетную образовательную программу (специальность) / с допустимой нормой отклонения/.

В соответствии с предлагаемыми ФГОС формами уроков, при проведении профориентационной работы со школьниками и учащимися колледжей могут быть проведены образовательные мероприятия, представленные в таблице 3. Является 
целесообразным разработать ряд сценариев указанных ниже форматов уроков в рамках МЭШ и отправить на дальнейшую модерацию с целью тиражирования опыта профориентационной работы в других образовательных организациях.

Представляется целесообразным форма взаимовыгодного сотрудничества, при которой преподаватели колледжа студентам ВУЗа преподают курс в рамках программы тренингов, например, по тематике «3-D моделирование при проектировании машиностроительных изделий» с получением соответствующего сертификата. Это позволит студентам пополнить свое портфолио и расширить поле профессиональной компетенции. В свою очередь, преподаватели ВУЗа для слушателей колледжа готовят онлайн курсы в рамках системы дистанционного обучения Moodle по тематике «Диагностика деятельности промышленной организации», «Бережливое производство», объем часов изучения которых можно будет перезачесть по учебным планам при продолжении обучения в ВУЗе по образовательной программе «Менеджмент промышленных организаций». Для преподавателей колледжа эти же курсы могут быть адаптированы с возможностью получения удостоверения о краткосрочном повышении квалификации (в объеме 72 / 144 часа). Таким образом, реализуется траектория непрерывного обучения на протяжении своей профессиональной карьеры. При рассмотрении кейсов от предприятий- работодателей рассматриваются преимущественно следующие вопросы:

Таблииа 3

Формы уроков по ФГОС в рамках профориентачионной деятельности

\begin{tabular}{|c|c|c|c|c|}
\hline пП & $\begin{array}{c}\text { Формы уроков по } \\
\text { ФГОС }\end{array}$ & 7-8 классы школ (МГОК) & $\begin{array}{c}\text { 10-11 классы школ } \\
\text { (МГОК) }\end{array}$ & Учащиеся колледжей \\
\hline 1 & $\begin{array}{c}\text { Уроки в форме } \\
\text { соревнований и } \\
\text { игр } \\
\end{array}$ & $\begin{array}{c}\text { Викторина «Менеджер или } \\
\text { экономист ?» }\end{array}$ & \multicolumn{2}{|c|}{$\begin{array}{l}\text { 1.«Турнир будущих управленцев» } \\
\text { 2. КВН «Менеджер в цифровом мире» }\end{array}$} \\
\hline 2 & $\begin{array}{c}\text { Урок на основе } \\
\text { нетрадиционной } \\
\text { подачи материала }\end{array}$ & \multicolumn{3}{|c|}{$\begin{array}{c}\text { 1.Творческий отчет (эссе) по результатам экскурсии в ВУЗ, посещения } \\
\text { мастер-классов, Дней открытых дверей. } \\
\text { 2. Вебинар «Как поступить на образовательную программу в ГУУ». } \\
\text { 3. Кейсы из практической деятельности компаний-резидентов технополиса } \\
\text { и вертолетного холдинга. } \\
\text { 4. Квест «Пройди путем технопредпринимателя». }\end{array}$} \\
\hline & $\begin{array}{c}\text { Уроки, } \\
\text { напоминающие по } \\
\text { форме публичные } \\
\text { выступления }\end{array}$ & $\begin{array}{c}\text { Диспут «Зачем } \\
\text { постоянно учиться в } \\
\text { профессии ?» }\end{array}$ & $\begin{array}{r}\text { 1.Конференция по } \\
\text { менеджеров промышл } \\
\text { реализации стратеги } \\
2 . \text { Семинар с участиел } \\
\text { «Московский вертол } \\
\text { Миля» «Конкурентосп } \\
\text { современ } \\
\text { 3.Аукцион активс } \\
\text { предп }\end{array}$ & $\begin{array}{l}\text { вопросам функции } \\
\text { нных предприятий при } \\
\text { импортозамещения. } \\
\text { представителей ОАО } \\
\text { тный завод им. М.Л. } \\
\text { собность выпускника в } \\
\text { ом мире». } \\
\text { промышленного } \\
\text { иятия. }\end{array}$ \\
\hline 4 & $\begin{array}{c}\text { Уроки, } \\
\text { имитирующие } \\
\text { деятельность } \\
\end{array}$ & $\begin{array}{l}\text { Деловая игра «Я - } \\
\text { предприниматель» }\end{array}$ & $\begin{array}{r}\text { 1.Деловая игра «Учет } \\
\text { органи } \\
\text { 2. Деловая игра «Бере }\end{array}$ & $\begin{array}{l}\text { атрат в промышленной } \\
\text { ации». } \\
\text { кливое производство». }\end{array}$ \\
\hline 5 & $\begin{array}{l}\text { Уроки в форме } \\
\text { мероприятий }\end{array}$ & $\begin{array}{c}\text { Экскурсии в ВУЗ на } \\
\text { Университетские } \\
\text { субботы, Дни открытых } \\
\text { дверей ВУЗа и кафедры }\end{array}$ & $\begin{array}{r}\text { 1.Экскурсии в ВУЗ } \\
\text { субботы, Дни откр } \\
\text { каф } \\
\text { 2. Ролевая игра «Ино } \\
\text { высокотехнологич } \\
\text { предпр } \\
3 . \text { Экскурсии в тех } \\
\text { компании-резиденты } \\
\text { секторов экономики }(5 \\
\text { также квс }\end{array}$ & $\begin{array}{l}\text { на Университетские } \\
\text { тых дверей ВУЗа и } \\
\text { дры. } \\
\text { транный инвестор на } \\
\text { ом промышленном } \\
\text { ıятии». } \\
\text { ополис «Москва» в } \\
6 \text { в разехнологичных } \\
6 \text { вастеры, а } \\
\text { нториум). }\end{array}$ \\
\hline
\end{tabular}

- «Нормирование на предприятиях оборонно-промышленного комплекса»; 
- «Мотивационная модель ценообразования и ее применимость в опытном производстве»;

- «Формирование сбалансированной системы показателей для руководителей производства»;

- «Формирование плана опытного производства с использованием теории ограничений Голдратта»;

- «Экспресс-обоснование экономического эффекта от внедрения инструментов бережливого производства».

Поиск обучающимися решения проблемы, изложенной в кейсе из практики деятельности предприятий реального сектора экономики, позволит приобрести навыки проведения практических расчетов и подготовки технико-экономического обоснования проектов. У отличившихся обучающихся возникает потенциальная возможность заключения отсроченного трудового договора $\mathrm{c}$ предприятиями, получения возможности бесплатного обучения по программам магистратуры ВУЗа.

Достаточно интересным представляется интеграция системы профориенационной работы ВУЗа с проектом «Профессиональная среда - построй свою траекторию !» (http://ps.dogm.mos.ru/about.html). Стартовав в 2015 году, настоящий проект существенно расширил масштабы своей деятельности, проводя более 700 мероприятий в год более, чем для 20000 школьников. Для ВУЗов является принципиально ванным использовать такие проекты в качестве своеобразных точек роста, поскольку она представляют собой новую форму сотрудничества школ и колледжей.

Т.е. не ВУЗ точечно подбирает колледжи и МГОКи в привязке под свои образовательные программы, а сразу начинает работать с кластером образовательных организаций. Например, в рамках реализации профориентационной работы кафедры «Управление организацией в машиностроении» возможна совместная организация мастер-классов, производственных стажировок, деловых игр и квестов для различных целевых аудиторий (школьники, обучающиеся колледжей и их родители) с ГАПОУ «Колледж предпринимательства № 11», ГБПОУ «Колледж малого бизнеса № 4» и ГБПОУ «Колледж связи № 54 им. П.М. Вострухина».

Таким образом, на основании рассмотрения педагогических условий, способствующих внедрению эффективных технологий профориентационной работы с обучающимися в системе образования «школа-колледж-ВУЗ», можно сделать следующие выводы:

1. Предложенные методические рекомендации по организации профориентационной работы с обучающимися, затрагивают вопросы взаимодействия ответственного лица с широким кругом заинтересованных лиц (от ответственного секретаря приемной комиссии, обучающихся, их родителей, учителей школ и преподавателей колледжей до представителей компаний-работодателей) прошли экспериментальную проверку при выстраивании взаимодействия ГУУ с двумя Московскими государственными образовательными комплексами (включающими 3 школы и 4 колледжа), двумя независимыми колледжами, одной независимой школой, технополисом «Москва» и его резидентами, а также вертолетным холдингом, показав свою жизнеспособность.

2.Сформулированные методические рекомендации для лиц, занимающихся профориентационной работой, представлены 17 пунктами и ориентируют на долгосрочный характер взаимодействия представителей образовательных организаций, предприятий реального сектора экономики, разработчиков онлайн курсов для обучения в рамках заключенных Соглашений о сотрудничестве и сетевом взаимодействии.

3. Рекомендации по организации профориентационной работы дополнены практической разработкой схемы одного из образовательных мероприятий - экскурсии для обучающихся в технополис «Москва», включающего около 92 компаний- 
резидентов из высокотехнологичных секторов экономики. Также в рамках профориентационной работы «ВУЗ - школам и колледжам» разработан сценарий образовательного мероприятия «Экскурсия в технополис «Москва»» на платформе Московской электронной школы (МЭШ). Предложенный спектр профориентационных мероприятий от экскурсий, диспутов, кейсов, деловых игр, квестов может быть разработан в качестве сценария уроков в МЭШ и растиражирован в качестве примера лучшей практики по другим образовательным организациям.

4. Учитывая становление цифровой экономики, глобализацию бизнеса, развитие сетевых форм взаимодействия и программ дистанционного обучения, профориентационная деятельность в системе образования «школа-колледж-ВУЗ» постепенно будет смещаться в интернет-пространство. В этом случае эффективность применения педагогических технологий для воздействия на обучающегося будет определяться качеством и разнообразием используемых информационнокоммуникационных технологий.

$$
* * *
$$

1. Донцов А. И., Донцов Д. А., Донцова М. В. Технологии профориентационного консультирования. Классический профориентационный подход Е. А. Климова // Прикладная психология как ресурс социально-экономического развития России в условиях преодоления глобального кризиса: материалы II межрегион. науч.-практ. конф., Москва, 11-13 ноября 2010 г.: кн. 1. - М.: Изд-во Моск. ун- та, 2010. - С. 60-63.

2. Паскарь В. С. Современные формы профориентационной работы в ВУЗах // Научно-методический электронный журнал «Концепт». - 2017. - T. 27. - С. 64-68. - URL: http:// ekoncept.ru/2017/574011.htm. (дата обращения: 14.01.2018).

3. Постановление Правительства Российской Федерации № 1297 от 01.12 .2015 года «Об утверждении государственной программы РФ «Доступная среда» на 2011-2020 годы». 